\title{
The Dynamics of The Democratic Process In Legal Politics In Indonesia and Egypt
}

\author{
Nahrowi $^{1}$, Masyrofah ${ }^{2}$, Nurul Handayani ${ }^{3}$ \\ Syarif Hidayatullah State Islamic University Jakarta Indonesia \\ d. \\ 10.15408/jch.v8i3.17071
}

\begin{abstract}
The implementation of democratic systems in several Muslim countries has obstacles. This is due to the development of people's thinking patterns about understanding democracy itself. Islam as a religion emphasizes the establishment of harmonious relations, but when applying the relationship of Islam and democracy in the life of the state does not necessarily be smooth at the level of practice. But on the other hand, It faced with the reality of the problems in implementing democratization in the Islamic world. Some countries claimed to succeed as democratic countries, generally after going through a transition period of transfer of government power. But on the contrary, not a few countries that have not or are not ready to accept change as a process of democratization are trapped in the struggle for power and lead to conflict and violence. Therefore it is important to discuss the challenges and obstacles of democratization in the Islamic world. With a normative-empirical approach, this article aims to analyze the problems of the democratization process in two Muslim countries, namely Indonesia and Egypt. This study found that the process of democratization as a part of the legal-political system in Muslim countries must adapt to the culture and political conditions of each country. The challenges of the democratization process in Indonesia and Egypt, namely the media, ideology, natural resources, common vision and mission in developing the country, strong commitment from all components of the nation, the political will of the head of state related to power-sharing and strengthening dialogue with the people.

Keywords: Democracy, Muslim Countries, Conflict of Power, Legal Politics
\end{abstract}

${ }^{*}$ Received: October 23, 2020, revised: November 21, 2020, accepted: November 11, 2020, Published: December 5, 2020.

${ }^{1}$ Nahrowi is a Doctor in Law from Faculty of Law Padjadjaran University West Java Indonesia, Lecturer of Department of Law, Head of master Islamic Family Law Department at Sharia and Law Faculty Syarif Hidayatullah State Islamic University Jakarta Indonesia,

2 Masyrofah is a Doctor in Islamic Politics from Graduate School Syarif Hidayatullah State Islamic University Jakarta Indonesia, Lecturer and Secretary of Islamic Constitutional Law Department of Sharia and Law Faculty Syarif Hidayatullah State Islamic University Jakarta Indonesia,

${ }^{3}$ Nurul Handayani is a Master in English from State Jakarta University Indonesia, Lecturer of Department of Law at Sharia and Law Faculty Syarif Hidayatullah State Islamic University Jakarta Indonesia,

*Corresponding author: nahrowi@uinjkt.ac.id 


\title{
Dinamika Proses Demokrasi Dalam Kerangka Politik Hukum Di Indonesia dan Mesir
}

\begin{abstract}
Abstrak
Penerapan sistem demokrasi di beberapa negara muslim memiliki kendala. Hal ini disebabkan semakin berkembangnya pola pemikiran masyarakat mengenai pemahaman demokrasi itu sendiri. Islam sebagai agama yang menitikberatkan kepada terjalinnya hubungan yang harmonis dalam kehidupan bernegara, namun ketika menerapkan hubungan Islam dan demokrasi dalam kehidupan bernegara tidak serta merta mulus pada tataran praktiknya. Idealnya sebuah negara yang menjalankan sistem demokrasi memiliki tingkat partisipasi masyarakat yang kian meningkat dalam turut serta membangun negara. Namun di sisi lain dihadapkan pada realitas adanya problematika dalam menerapkan demokratisasi di dunia Islam. Ada negara yang diklaim berhasil sebagai negara demokratis, umumnya setelah melewati masa-masa transisi perpindahan kekuasaan pemerintahan. Namun sebaliknya, tidak sedikit negara yang belum atau tidak siap menerima perubahan sebagai proses demokratisasi justru terjebak dalam perebutan kekuasaan dan berujung kepada konflik dan kekerasan. Oleh karena itu penting untuk dibahas tentang apa saja tantangan dan hambatan demokratisasi di dunia Islam. Dengan pendekatan normatifempiris, artikel ini bertujuan untuk menganalisa problematika proses demokratisasi di dua negara Muslim yaitu Indonesia dan Mesir. Studi ini menemukan bahwa proses demokratisasi yang merupakan bagian dari sistem politik hukum di negara muslim haruslah menyesuaikan dengan kultur dan kondisi politik masing-masing negara tersebut.
\end{abstract}

Kata Kunci: Demokrasi, Negara Muslim, Media, Konflik Kekuasaan, sistem hukum ketatanegaraan

\section{Динамика Процесса Демократии В Рамках Правовой Политики В Индонезии и Египте}

\begin{abstract}
Аннотация
Внедрение демократической системы в нескольких мусульманских странах сталкивается с препятствиями. Это связано с развитием у людей образов мышления в отношении понимания самой демократии. Ислам, как религия, подчеркивает установление гармоничных отношений в государственной жизни, однако практически применение исламских и демократических отношений в жизни государства не обязательно гладко. В идеале страна, в которой действует демократическая система, дожна иметь все более высокий уровень участия общественности в строительстве страны. Однако, с другой стороны, существуют проблемы в применении демократизации в исламском мире. Есть страны, которые считаются успешными как демократические страны, как правило, после завершения переходного периода передачи государственной власти. Напротив, многие страны, которые не готовы или не готовы принять перемены как процесс демократизации, попадают в ловушку борьбы за власть и приводят к конфрликтам и насилию. Поэтому важно обсудить, какие существуют проблемы и препятствия на пути демократизации в исламском мире. Данная статья с нормативно-эмпирическим подходом направлена на анализирование проблем процесса демократизации в двух мусульманских странах, а именно Индонезии и Египте. Это исследование показывает, что процесс демократизации, который является частью правовой политической системы в мусульманских странах, должен адаптироваться к культуре и политическим условиям каждой страны.
\end{abstract}

Ключевые слова: Демократия, Мусульманское Государство, Сми, Конфликт Власти, Конституционно-Правовая Система. 


\section{A. INTRODUCTION}

Islam is a religion for all ethnic groups and nations as well as all times and places. He descended as a blessing and guidance for mankind (rahmat li al'alamiin) in this life, not only for Muslims, but also for mankind in the universe and even all creatures in this world. Therefore, in matters of a fundamental nature, Islam teaches universal values, which are recognized by all mankind, especially civilized nations. Meanwhile, in matters of a practical or technical nature, some of his teachings are particular in nature, so that these teachings differ from other religious teachings or social and state (ideological) systems.

In terms of substance, the presence of Islam is not something new at all because this religion is a continuation of the religions of Allah that was revealed to the previous apostles. Islam functions as a correct (mushaddiq) of the teachings of these religions and to correct deviations committed by its adherents. However, in reality, at this time there are fundamental differences in theology (akidah) between Islam and these religions, giving rise to the assumption that their religious teachings are completely different from other religions and claim that only their religion is the most correct. Masykuri Abdillah (2011: $x$-xi) stated that the facts that occur in certain cases trigger conflict or disharmony between the adherents. The fact shows that many governments in Muslim countries practice an authoritarian and despotic system against their people and the occurrence of violence by certain Islamic groups has created a negative image against Islam, especially in the international context.

The revival of Islam and democratization in the Muslim world is taking place in a dynamic global context. In various parts of the world, people are calling for the revival of religion and democratization so that both become the most important themes in today's world problems. The strengthening of communal identities and demands for people's political participation arise in a complex world environment where technology is increasingly strengthening global relations, while at the same time local, national and local cultural identities are still very strong (Esposito \& Voll, 1999: 11).

Various political systems were prevailing in the Muslim world at the beginning of modern times. Some of the largest empires, for example, the Ottoman Empire in Europe and the Middle East and the Moghul Sovereignty in India, were ruled by sultans. Meanwhile, Shia Iran is led by the shah. In other parts of the Muslim world, there were smaller kingdoms ruled by local aristocrats, such as the Imam in Yemen and the leaders of the Persian Gulf 
region. All these countries, including facing the challenges of modern social and political changes.

The role of Islam in politics began to change significantly in the 1970s. Instead of merely being a reactive element in the political community, Islamic groups can emerge as a source of the initiative for political development and change (Esposito \& Voll, 1999: 5). Islamization and Democratization have become an important issue in the Muslim world today, which revolves around the compatibility between Islam and democracy and the role of new Islamic movements in the process of political evolution in Muslim societies.

In the Muslim world, there has been an important and very visible Islamic revival. This confirmation of faith and identity has a great influence on all aspects of human life. Simultaneously with the emergence of the Islamic revival, there have also been growing demands for popular participation in the political system. The Islamic revolution that overthrew the Iranian empire in 1979 was one of the first popular revolutions in the last quarter of the twentieth century against a modern authoritarian political system. In the early 1990s another Islamic movement, the Islamic Salvation Front (FIS) party, was violently suppressed after dramatically outperforming Algeria's authoritarian government party, the National Liberation Front (FLN), in government-run free elections. In various parts of the Islamic world, one of the important issues that determine the future of politics is the relationship between the forces of Islamic awakening and the development of a democratic political system.

\section{Literature Review}

According to Anthony Bubalo et al (2008: 5), that democratization is most likely to succeed when it results from endogenous drivers and processes. Yet it is also true that the international community shapes and affects these processes in myriad ways, from the human rights representations made by individual countries to the provision or withholding of aid and financial assistance, to the recognition afforded by new governments. In short, even if it is not promoting it, the international community will continue to influence and respond to democratization and political change in the Muslim world.

Amal Jamal (2009: 3) said that the relationship between the state, religion, and democratization should be viewed in dynamic rather than static terms. Democratization is a non-unitary and contingent political process as well as a context-dependent variable that may include various and sometimes even contradictory processes. In some cases, the de-institutionalization of religion as 
exclusive authority over the spiritual and personal life of individuals facilitates freedom of religion and from religion, thereby representing democratization.

Based on research by Michael Buehler (2009: 53) that the ease with which democracy is thriving in Muslim-majority Indonesia is usually ascribed to the moderate forms of Islam Indonesians have adopted. "Much of the literature during the twentieth century portrayed the [Indonesian] Muslim community in largely benign terms. There were several interlinked aspects to this approving commentary. The first remarked on the myriad ways in which local Muslim communities had 'indigenized' Islam, blending it with preexisting religious practices to produce richly distinctive variants. Moreover, this Indonesianized form of Islam bore none of the severity and rigidity attributed to Middle Eastern forms, earning it praise for its moderation and tolerance. Some scholars even approvingly observed that large numbers of Muslims appeared lax in their devotions and heedless of all but the most basic requirements of Islamic law," Greg Fealy and Sally White note. The perception that it is mainly the peculiarities of Indonesian Islam that make it compatible with democracy is reflected in a growing number of surveys and studies conducted since 1998 that set out to show that Indonesian Muslim is against the implementation of shari'a laws, dislike parties with an Islamist platform, and embrace the ecumenical Pancasila ideology of the Indonesian state.

Etymologically, democracy consists of two words that come from Greece, namely "demos" and "cratein" or "cratos". Demos means the people or inhabitants of a place and cratein or cratos means power or sovereignty. So "demos-cratein" or "demos-cratos" means the power or sovereignty of the people. In a state, the people have the highest power (government of rule by the people). The people are the policyholders in the life of the nation and state (Ubaedillah, 2000: 162).

In terms of terminology, democracy according to the large Indonesian dictionary is defined as an idea or view of life that prioritizes equal rights and obligations as well as equal treatment for all citizens. (Depdikbud, 1999: 220) This shows that democracy is a way of life that emphasizes the principles of equality, openness, mutual respect, responsible freedom, developing tolerance, and fair play. The opinions of the figures about the definition of democracy, namely:

a. According to Joseph A. Schmeter 
Democracy is an institutional plan to reach decisions where individuals gain the power to decide to utilize a competitive struggle for the votes of the people.

b. According to Sidney Hook

Democracy is defined as a form of government in which important government decisions, either directly or indirectly, are based on majority agreement given freely from adult people. Based on the opinion of the two figures that in democracy, the people are the holders of power, makers, decision-makers, and highest policy holders in the administration of the state and governance as well as controlling their implementation, either directly or indirectly by representative institutions which are the representative institutions. Democracy, which is an idea or view of life that prioritizes equal rights, and equal obligations and treatment for all citizens without exception, is truly a noble ideal. This ideal will be realized if there is active participation from all levels of society and a strong will from the government (political will). On the other hand, these ideals are nothing more than "dreams without meaning" without the active participation of the community and the strong will of the government to implement them (Mufid, 2004: 69).

The philosophy of democracy stated by Western leaders is realized through community contracts, by transferring people's power through their representatives through elections and no longer directly through the people, namely, the people are given the right to determine their representatives. Democracy undergoes a process of change by following the political conditions of the country that practices it (Awang, 2007: 60).

Historically, democracy was born from the idea of secularism, namely the separation between religion and state. Therefore, it is understandable that currently there are debates or studies on religion and democracy. This is because of the theory of secularism and modernization, religion is considered a force for authoritarianism and an obstacle to the attainment of "modernity and rationality" which is a precondition for the realization of democracy. Indeed, there is no agreement among scholars and observers on the compatibility of religion and democracy.

Today democracy is defined as a word that implies values, the struggle for freedom, and a better way of life. Democracy is not only a method of majority rule through popular participation and free competence, but also contains universal values, particularly the values of equality, freedom, and 
pluralism, although the operational concepts vary according to the cultural conditions of a particular country (Abdillah, 1999: 74).

Among Islamic experts, there are differences in responding to issues of shura and democracy. Some view shura and democracy as two identical things; others view them as two opposing concepts; while others consider that the two of them have close similarities, besides that there are also differences.

The word "shura" comes from sya-wa-ra which etymologically means removing honey from the beehive. In line with this definition, the word shura, or in Indonesian is "deliberation" which means anything that can be taken or removed from others (including opinions) for goodness. This implies that bees emit honey which is useful for humans. Thus, etymologically, shura means capturing the best ideas by gathering many people who are assumed to have a reason, argumentation, experience, sophistication of opinion, and other prerequisites that support them to give the right opinion and the right decision.

According to Sadek J. Sulaiman (1988: 97), Oman's former ambassador to the United Nations put forward seven main principles of the democratic system:

1. Freedom of speech. Every citizen has the right to express his opinion without feeling afraid. In a democratic system, this is to control the power to run properly.

2. The implementation of an honest and fair election as a constitutional means of assessing whether the government in power deserves to be supported again or needs to be replaced by another.

3. Power is held by the majority without neglecting minority control and recognizing the right of a group's opposition to the government.

4. In a democratic system, political parties play an important role. The people have the right freely to support which party is more following their views and choices.

5. There is a separation between legislative, executive, and judicial powers. Then there will be checks and balances, so that power will be avoided from exploitative practices.

6. In a democracy emphasizes the rule of law. All individuals must submit to the law, regardless of their position and social status.

7. In a democracy, all individuals or groups are free to do actions. Every individual has property rights, without being disturbed by any party. 
Democracy as an idea based on the principles of freedom, equality, and human sovereignty to determine matters relating to public affairs, is fundamentally in line with Islam. This will appear in at least two ways. First, in Islamic teachings about the values of life that must be used as a reference, namely:

a. Al-musawah or equality of humanity before Allah SWT. In the Islamic conception, all humans are equal in dignity and position, there is no difference before Allah except in terms of piety based on QS: al-Hujurat (49) verse 13

b. Al-hurriyah, freedom or freedom based on moral and legal responsibility, both in this world and in the hereafter. This principle is based on a concept that respects human values which view humans as honorable beings who are given the convenience of Allah to have freedom of choice. In Islam, this principle is the verse of the agreement when humans justify the rububiyah's of Allah, this is explained in Surat al-A'raf (7) verse 172.

c. Al-ukhuwwah, brotherhood among humans as a species created from the same raw materials, based on QS al-Baqarah (2) verse 213.

d. Al-'Adalah, justice which is essentially the fulfillment of human rights as individuals and as citizens of society, based on QS al-Ma'idah (5) verse 8.

e. Al-shura, deliberation, where every member of the community has the right to participate in public affairs that concern common interests. In this case, prioritizing the principle of deliberation contained in Surah al-Shura (42) paragraph 38.

f. Al-Mas' uliyyah / responsibility, the principle of responsibility that is borne by each holder of power. It should be understood that power is a mandate to be aware of and not a blessing to be grateful for. Especially for the authorities, the meaning of mandate means a dual function, namely the mandate of Allah and the mandate of the people (Iftihah, 2014: 40-41).

\section{B. METHODS}

According to Musni Umar (2004: 6), quoting the opinions of John L. Esposito and James P. Piscatori, he stated that there is opposition to democracy among Muslims in various countries in the Islamic world. This is due to an understanding of the origins of democracy and Islam. Islam and its system are believed by its adherents to be a divine revelation, while democracy is born from human reasoning. So it can be understood if some Muslims argue that the pillars of democracy that are being practiced today are opposed to Islam. But on 
the other hand, the concept of democracy is still under Islam, so it can be accepted and practiced, provided that its implementation is adjusted to the situation and conditions in each country. Because what is good for the United States or Western countries is not necessarily suitable or suitable for people in Asia, one of which is Indonesia. Democracy as the result of human ijtihad must be harmonized so that its application is in line with and in line with the culture and needs of each society, nation, and state.

Some of the main elements of democracy that are often used as reasons for opponents of democracy in the Islamic world, namely: 1). Sovereignty is in the hands of the people 2). People as a source of power 3). Guarantee of four main freedoms, namely freedom of religion, freedom of speech, freedom of ownership, and personal freedom. As for the freedom of speech (freedom of speech) is recognized and highly respected in Islam, even doing ijtihad has an honorable place in Islam. Besides, the principle of deliberation is one of the principles of state life in Islam. In terms of religious freedom, according to Islam there is no compulsion to choose Islam, but if you have chosen Islam, then you leave Islam then that person is called an apostate. Freedom of ownership is also regulated in Islam, that it is not permissible for reasons of freedom of ownership to try to acquire property by justifying any means.

Theologically acceptance of democracy is based on the teachings of the Koran and historical practices during the time of the Prophet and al-Khulafa alRasyidun. They refer to the Koran (3: 159)." According to Muhammad Dhiya Al-Din Rais, Islam and democracy have similarities in terms of the political system thinking between the people (ummah) and the rulers and the responsibility of government. The elements and features of democracy are also contained in Islam. In terms of the definition of democracy, namely the government from, by, and for the people, it is contained in the Islamic state system, with the exception that the people must understand Islam comprehensively. Islam and democracy, both guarantee the existence of certain political bases, for example, the principle of equality before the law, freedom of thought and belief, social justice, guaranteeing certain rights, the right to live freely, the right to work, and others.

On the other hand, according to Dhiya Al-Din Rais, there are differences between Islam and democracy, namely: first, the meaning of "nation" or "people" in democracy (West) is different from Islam. In the concept of Western democracy, "Nation" or "Ummah" is limited by geographic location, climate, blood ties, type, language, and other customs called nationalism or racism accompanied by fanaticism. In Islam, "nation" or "ummah" is not limited 
by geographical location, blood, or language, but by ties to faith. Second, the goals of Western and Islamic democracy are different. If Western democracy aims at a worldly or material nature, namely to only realize the welfare of the people in the life of the world, then the goal of Islam does not only cover worldly or material problems but also to achieve more primal and fundamental spiritual needs. Third, the power or sovereignty of the people (people) is absolute in Western democracy. In Islam, the power or sovereignty of the people (people) is not absolute but is bound by the provisions of religious law (sharia) and the actions of the people are not allowed to go beyond the boundaries of sharia (Thaha, 2005: 50).

Therefore according to Dhiya Al-Din Rais that the Islamic political system looks unique which is called "Islamic democracy". This political system is humane, comprehensive (international), religious, ethical, spiritual, and material at the same time. So he stated that Islam is not the same as "democracy" which recognizes that power or sovereignty is only held by the people; Islam is not the same as "autocracy" which considers the highest power in the hands of the rulers; Islam is not in line with "theocracy" which only recognizes the power in the hands of religious figures and Islam is also different from "Nomocracy" which makes law the highest power.

There are three important reasons for discussing Islam and democracy. First, the sources and reference materials for the discussion are very numerous and rich. Second, the complexity of the problems of Islam and democracy being discussed. Third, the ideological views of various Muslim community groups. There are three groups or views of political theorists and practitioners towards democracy, based on their paradigms and theological arguments, which have developed in the Muslim world, namely (Thaha, 2005: 40): First, conservative Islamic groups and views called "counter blocs". This group rejects any relationship, let alone integration between Islam and democracy, which is a product of Western political thought. This group argues that Islam rejects the presence and practice of (modern) democracy that was built by the West, especially the Europeans. This block was represented by Shaykh Fadhallah Nuri, Muhammad Husain Thaba'thaba'i from Iran, Sayyid Qutb (1906-1966) and Al-Sya'rawi from Egypt, Ali Benhadj and Abdelkader Moghni from Algeria, Hasan Al-Turabi from Sudan and Adnan Aly Ridha Al-Nahwy, Abd Al-Qadim Zallum (Kamil, 2002: 47).

Second, liberal Islamic groups and views are called "pro bloc". They argue that Islam and democracy are closely related and side by side. They accept democracy as something universal, which can live and develop in 
countries of the Muslim world. This block was supported by Muhammad Abduh (1845-1905), Rasyid Ridha (1865-1935), Shaykh Mahmud Syaltut, Ali Abd Al-Raziq (1888-1966), Khalid Muhammad Khalid, Muhammad Husein Haikal, Toha Husein (1891), Zakaria. Abd Al-Mun'im Ibrahim Al Khatib, Mahmud Aqqad, Muhammad Imarah from Egypt, Sadek Jawad Sulaiman from Oman, Mahmoud Mohamed Taha, and Abdullah Ahmad Al-Na'im from Sudan, Bani Sadr, and Mehdi Bazargan from Iran, Abbasi Madani from Algeria and Hasan Al-Hakim from the United Arab Emirates (Kamil, 2002: 53).

Third, groups and moderate Islamic views are called non-aligned ones. According to this group, they do not take sides with one group, both contra, and pro, their position is in the middle of the two groups. They tried to find common ground between the two groups above, by pointing out the similarities between Islam and democracy. Muslim thinkers who belong to this group are 'Abu Al-A'la Al-Maududi and Muhammad Iqbal (1876-1938) from Pakistan, Imam Khomeini and Abdul Karim Soroush from Iran, and Muhammad Dhiya Al-Din Rais from Egypt. They found and acknowledged the similarities between Islam and democracy, including the differences between the two.

\section{RESULTS AND DISCUSSION}

\section{The Relationship Between Islam and The State}

The debate over the relationship between Islam and the state has been going on since the 1980s, when Islamic groups involved themselves in general elections, especially in Egypt. Then, when the Islamic Salvation Front (FIS) won the election in Algeria which took place in December 1990. At that time, the government (military) alleged that some FIS figures issued several statements rejecting democracy (Huwaydi, 1996: 2).

Among Muslim scholars and intellectuals in the world, there are three views on the relationship between Islamic teachings and the state issue.

First, are the conservative groups, which maintain the integration between Islam and the state, because according to them, Islam has completely regulated the social system. This group consists of:

a. Traditionalists, that is, still maintain the traditional/medieval Islamic political thought and practice, such as Rasyid Ridha. 
b. Fundamentalists, namely those who want to reform the social system by completely returning to Islamic teachings and rejecting human-made systems, such as Sayyid Qutb, Abula'la Maududi, and Hasan Turabi.

Second, the modernist group, which argues that Islam regulates mundane (social) problems only on the basics, while technically they can adopt another system, in this case, the Western system which has shown its advantages. Among the figures of this group are Muhammad Abduh, Husein Haikal, and Muhammad Asad.

Third, it is a secular group that wants to separate Islam and the state, because according to this group Islam, like other religions, does not regulate mundane problems, as the state practice found in the West. Among the figures of this sect are Ali Abdurraziq and Thaha Husein (Sjadzali, 1990: 1).

The relation of Religion (Islam) and the state according to the sociology of Islamic political theorization formulates several theories about the relationship between religion and state. This theory can be known through 3 paradigms of thought, namely:

1. Integralistic paradigm (united paradigm). Integralistic paradigm is a paradigm that places religion and state as a whole. The area of religion includes both politics or the state Therefore, according to this paradigm, the head of state is the holder of religious power and political power. Its rule is administered based on "divine sovereignty," because supporters of this paradigm believe that sovereignty originates and is in the "Hand of God". Imam Al Ghazali in his book Al Iqtishad fil I'tiqad said: "It is said that religion and state are twins. It is also said that religion is the foundation (principle) and power is the guardian. Everything that is without foundation will inevitably collapse and everything that is not guarded will vanish." Supporting figures for this paradigm include Imam Khomeini, Mohammad Natsir, Zainal Abidin Ahmad.

According to Imam Khomeini, "in an Islamic state, the authority to determine the law rests with God. No one has the right to enact laws. And only God's law can apply. Abu al-A'la al-maududi added: "Sharih is a perfect life scheme and covers the whole social order, nothing is more and nothing is lacking". According to Mohammad Natsir's view on the relationship between religion (Islam) and the state as stated in his book entitled Islam as an ideology, Natsir discusses the issue of the relationship between Islam and the state based on his description of the verse of the Qur'an: "and we do not make humans, but so that they worship to Me "(an-naml verse 56) from this verse Natsir develops his theory by saying:" Muslim life on this world with the idea of life to become a 
servant of Allah with the full meaning, namely a servant of Allah who achieves world glory. and victory in the hereafter. The world and the hereafter cannot be separated from their ideology.

Furthermore, the statement that the state as a state as well as a world power is absolute for the Qur'an, because only then can its rules and teachings be implemented in real life. For Natsir, the state is a tool for Islam to carry out Allah's laws for the sake of human safety and security. Because of that Natsir defended the principle of religious unity with the state. According to Zainal Abidin Ahmad's views in his speech before the Constituent Assembly, he put forward two main reasons why he chose Islam as the basis of the state. First, the ruling group must obtain the approval of the majority group of people, and the second minority group must be guaranteed their rights. The first condition, according to him, is clear, because the majority of Indonesians are adherents of Islam, but when viewed from a political point of view, this kind of reason is inclusive, Ahmad quotes the opinion of a writer who says that in Islam "... religion is for God, and homeland. for humanity together ", regardless of religion, racial differences, their political tendencies, etc. As for the second principle, Ahmad guarantees that in an Islamic state like the one created by the Prophet in Medina, the citizens will not only consist of Muslims, but also hypocrites and Jews. They all enjoy the same status. These non-Muslims are known as "Mu'ahad". They are people who are not Muslims, who have pledged allegiance to an Islamic state, namely a minority group in an Islamic state. Allah guarantees the right to the safety of their souls. Sahih hadith from bukhari: From Abdullah bin Amru r.a. from the Holy Prophet. He said: "Whoever kills a mu'ahad will not smell the smell of heaven, while the smell is as far as forty years." Examples of countries that use this ideology are Saudi Arabia, Malaysia, Iran, Mauritania, Pakistan.

2. Symbiotic Paradigm. This paradigm places the relationship between Religion and State reciprocal and mutually necessary. In this case, religion needs a state, because, with the state, religion can develop. On the other hand, the state also needs religion, because, with religion, the state can develop ethical and moral-spiritual guidance. Al Mawardy said: "the leadership of the state is an instrument to continue the prophetic mission in maintaining religion and governing the world". This argument is supported by Ibn Taymiyyah: the existence of a power that regulates human affairs is the greatest religious obligation because, without state power, religion cannot stand tall."

3. Secularistic Paradigm. This paradigm proposes the separation of religion from state and separation of state from state. Ali abd Ar-Raziq 
explained: "Islam does not establish a particular government regime, nor does it base on Muslims a certain system of government through which they must be governed, but Islam has given us absolute freedom to organize the state according to intellectual, social conditions, and the economy that we have and taking into account social developments and the demands of the times."

Meanwhile, according to Nurcholis Madjid, religion is a spiritualpersonal problem that cannot, cannot, and cannot interfere in state affairs which are collective rational problems. Religion and state have their dimensions with different approaches. Therefore, according to Nurkholis Madjid, Islamic identity cannot be applied to the state, because the state is one aspect of worldly life that has a rational and collective dimension, while religion is another aspect of life (ukhrawi) whose dimensions are spiritual and personal. Examples of secular countries are America, England, and so on.

According to Abdur Rahman Wahid (Gus Dur), there are three kinds of responses in the relationship between Islam and the state, namely integrative response, facultative response, and confrontational response. In an integrative response, Islam eliminates its formal position and in no way connects religious teachings with the state. Meanwhile, the facultative response, if their power is big enough in the parliament, the Muslims of the Islamic movement, will try to make laws and regulations following Islamic teachings. Meanwhile, the confrontational response was to reject the existence of things deemed "unIslamic" from the beginning.

\section{Islamic Awakening and the Wave of Democracy in Muslim Countries}

The officially recognized democratic model as well as various democratic concepts in the Western world have influenced the democratization process in the Muslim world. The globalization of communication has enabled Muslim scholars to be actively involved in broader debates about democracy. The debate between the "official model" of the Western democratic system and its criticisms influences the response of Muslims to Western policies and changes at the local level. Several Muslim thinkers have attempted to define Islamic democracy. They believe that the global processes of religious revival and democratization, especially in the Muslim world, really complement each other. The two processes will conflict if "democracy" is defined in a very limited way and is seen as possible only if the typical Western European or American institutions are applied, or if the main principles of Islam are traditionally defined and rigidly defined. 
The term democracy has been accepted by almost all governments in the world, even authoritarian governments use democratic attributes to characterize their regimes and aspirations. As a result, its use has grown into such as "Liberal democracy", "Guided Democracy", "People's Democracy", Socialist Democracy "and so on. Changes in the use of the term to bring the concept of democracy closer to the culture of a particular society and to justify the political system proposed by certain governments. Today the terms democracy and the process of democratization have become international themes, especially after the fall of the Socialist regimes in Eastern Europe (Abdillah, 2011: 3).

According to Samuel P. Huntington, the current process of democratization is called the "third wave of democracy" which began in 1974. Between 1974 and 1990, at least 30 countries were in transition to democracy. The first wave of democracy began in the 1820s and continued for nearly a century until 1926, resulting in approximately 29 democratic states. However, when Mussolini's rise to power in Italy marked the start of the "first wave of decline" in 1942 it had reduced the number of democratic states in the world to 12 countries. The Allied victory in World War II started the second wave of democracy that culminated in 1962 with 36 countries governed democratically, but this was followed by a "second wave of decline" between 1960-1975 which resulted in the number of democratic states falling to 30 (Huntington, 1991: 12).

There are at least five main factors that significantly influence the events and timing of the third wave of democracy, namely:

1. A deep problem of legitimacy regarding authoritarian regimes in a world where democratic values are widely accepted, along with their reliance on successful administration and their inability to maintain "legitimacy for such administration" due to economic and sometimes military failures.

2. The unprecedented growth of the global economy in the 1960s has raised living standards, increased education, and expanded the urban middle class in many countries.

3. A striking shift in the doctrine and activity of the Catholic Church, manifested at the Second Vatican Council (Second Vatican Council) in 19631965 and the change in the national Catholic Churches from defenders of the status quo to fighting authoritarianism.

4. Changes in foreign policies, especially in large parts of the European community, the United States, and the Soviet Union. 
5. "Snowballing" or demonstrations influenced earlier transitions in the third wave to encourage and provide models for further democratization efforts (Huntington, 1991: 13).

In the context of Muslim countries, Muslim scholars claim that Islam and democracy are compatible. Many governments in Muslim countries claim that their political systems are moving towards democracy, with their respective interpretations of democratization. The Saudi government is one of the few governments in Muslim countries that openly reject a democratic system because according to King Fahd, democracy is incompatible with the people of Saudi Arabia. The increasing participation of Islamic movements in the democratization process in the late 1980s and 1990s continued to move towards centers of power. This tendency raises problems regarding the compatibility between Islam and democracy, especially because democracy is based on secularism, whereas Islam is a religion based on a belief in God.

John L. Esposito and James P. Piscatori argued that both the principles of democracy and the democratization process were the subject of heated debate among Muslims. While radical Muslims reject all forms of parliamentary democracy as a form of westernization and not following local traditions, on the other hand, Islamic activists try to implement democratic ideas and processes. Even trying to implement political programs such as Islamic movements in various Muslim countries such as Algeria, Egypt, Jordan, Pakistan, and Tunisia which carry out the process of democratization in the political system and have succeeded in winning parliamentary seats and occupying cabinet positions (Esposito \& Piscatory, 1991: 428).

The theme of Islam and democracy will continue to be discussed in line with the wave of democratization in Muslim countries. Since 2011 the Arab Spring has been born, which has resulted in serious problems and obstacles, both in Egypt, Tunisia, and Libya. Even in Indonesia and Turkey as Muslim countries that are considered the most democratic, democratic practices are also inseparable from challenges and obstacles. The term democracy has been known since the 5th century BC, initially as a response to the bad experiences of monarchy and dictatorship in the ancient Greek city-states. Meanwhile, modern democracy developed from the ideas and institutions and traditions of the enlightenment that began in the 10th century, including the ideas of Niccolo Machiavelli, Baron de Montesquieu, and Jean-Jacques Rousseau. However, there is an opinion in a book written by Franz Rosenthal entitled The Muslim Concept of Freedom Prior to the Nineteen Century which states that the idea of the essence of democracy was put forward by the Muslim philosopher Al- 
Farabi (d.950 AD) before the intellectual thought of the Enlightenment emerged. Then the study by John Keane in his book The Life and Death of Democracy that classical democracy had begun in Mesopotamia (c. 250 BC) which spread through Greece and matured in Islamic civilization around 950 AD (Abdillah, 2011: 42).

These findings can certainly strengthen the existence and practice of democracy in the Middle East region because democracy is nothing new for the people of the Middle East. However, in general, democracy has not been practiced in areas where the majority of the population is Muslim. Although almost all governments in Middle Eastern countries claim that they implement a democratic system. According to Muslim scholars and intellectuals, there are three differences of opinion about democracy, namely; a). Those who support democracy with certain adjustments; b). Those who reject democracy and consider it incompatible with or against Islam; c). Those who fully support democracy based on secularism.

However, some observers argue that based on the political reality of Islam, it shows that Islam is not compatible with democracy. Judith Miller argues that despite their committed rhetoric to democracy and pluralism, nearly all militant Islamists oppose both. Other observers such as John L. Esposito and John O. Voll argue that Islam is not inherently opposed to democracy. Islam and politics as a program for religious democracy and not as an agenda for jihad or terrorism.

As for political Islam movement organizations, some groups reject democracy, such as the Al-Ikhwan al-Muslimun Qutbiyyah faction (followers of Sayyid Qutb), Salafi groups (including the An-Nour Party in Egypt), and Hizb ut-Tahrir. However, more organizations accept it than reject it, such as the moderate Brotherhood of the Hudaibiyah faction (followers of Hasan Hudaibi), the En-Nahdah Party led by Rachid Ghannushi (Tunisia), and so on (Abdillah, 2011: 43).

\section{Challenges and Barriers to Democratization in Muslim Countries}

According to Masykuri Abdillah (2016: 1), in the early 1990s a Muslim country that was considered to have implemented substantive democracy was Turkey, then in the late 1990s, along with the collapse of the New Order regime and the emergence of the reform era, Indonesia also implemented a democratic system. Furthermore, in the early 2010s, there were more and more democratic Muslim countries at the same time as the emergence of the Arab Spring in 2011, 
but only Tunisia was considered to have successfully passed the transition period of transition of power or transition to democracy. In the end, every Muslim country will encounter challenges and obstacles in the process of democratization, both at the stage of democratic transition and democratic consolidation.

\section{a. Indonesia}

Indonesia already has a democratic culture which is translated into the conceptions of "populist", "kinship" and "gotong royong". One of the principles of democracy adhered to by the Muslim community in Indonesia is one of the principles of Pancasila which is formulated into "democracy led by wisdom in deliberation/representation". These precepts seem to be the basic principles of Indonesian democracy. The practice of democracy or empirical democracy that has taken place in Indonesia proves that the Indonesian Muslim community has practiced democracy whose development has fluctuated or ebbed. Sometimes following the path of democracy and sometimes deviating from the real path of democracy. However, Indonesia has experienced and felt the bitterness of democratic life. In early 2000, it was stated that Indonesia, including Bangladesh and Pakistan, were categorized as areas of the non-Arab Muslim world that had good prospects for democratic growth.

This assessment is inseparable from the reality related to historical, sociological, and political processes in the growth and formation of Islamic traditions that tend to be accommodative and tolerant of local traditions and culture, including those from the West. Indonesia firmly states that it does not adopt Islam as a political ideology and at the same time does not adopt a secular ideology.

Since the beginning, Indonesia as a Muslim country with a Muslim majority has been declared a democracy, although in practice it has had its ups and downs. The emergence of the reform era marked by the collapse of the New Order regime in 1998 became the starting point for the transition to a substantive democracy. The democratization process includes two stages, namely democratic transition and democratic consolidation. At the transitional stage, political reform has been successfully carried out, especially in the form of amendments to the 1945 Constitution, limiting the power of the president, strengthening the role of the DPR, free elections, and guaranteeing freedom for citizens. This transition has been successfully passed and ended with the successful implementation of the first direct election in 2004 in the era of Megawati Soekarnoputri's reign. The next period, namely 2004 until now, is a 
stage of democratic consolidation. At this time Indonesia still experienced problems and obstacles to civilized democracy (Abdillah, 2011: 45).

Theoretically and practically, democracy in Indonesia still faces various challenges, not only as a result of different views on the concept of democracy but practically some problems constitute challenges, namely: first, issues of ethnicity, culture, and religion. Indonesia is one of the countries in the world that is multi-ethnic, cultural, and religious. Of course, this plurality has positive and negative potentials. If it is directed towards the progress of the nation, it will give birth to great power as the unity of the Indonesian nation. On the other hand, if it is mishandled, it will cause disastrous consequences, namely conflicts between ethnic groups, cultures, and religions. Cases that have occurred in the reform era include conflicts between ethnic Dayaks and Madurese in Sampit (Kalimantan), conflicts between Muslims and Christians in Ambon (Maluku), and Poso (Central Sulawesi) which have resulted in large casualties and property.

Second, the understanding of Islamic teachings is still minimal. Islam is a religion that guides humans and people who are devout and merciful for the entire universe. The concept of shura as instructed in the Koran has not been properly studied and practiced. Third, there is a limited number of strong and independent middle class that can act as a driving force in implementing democracy. According to William Liddle, at least academically if democratization is to be carried out, then the first condition that must be fulfilled is the fostering of a growing middle class, namely a social group that is economically quite free. Fourth, the low level of education of the majority of Indonesians. This has an impact on democratic education in Indonesia. So that in the future the public can understand more about the process of democratization in Indonesia.

The enduring role of religion and its place in the daily life of different societies make it necessary to escape judgmental assertions and look for analytical tools that help in understanding its impact on the chances of democratization. On the one hand, dismissing the political importance of religiosity or adopting dichotomous models that view democracy and religion as two antagonistic world views and authority systems is reductive. On the other hand, adopting one hegemonic state religion is counter-democratic not only in pluralistic and multi-religious societies but also in homogenous religious ones. In many democracies, such as the United States, the United Kingdom, Germany, Sweden, Denmark, and others, religion and religious institutions still play major roles without clashing with democratic freedoms. 
As some Orthodox Christian and Islamic states have demonstrated, including, Greece and Indonesia, no religion has proved itself to be immune to democracy and the changes that it brings. Besides, processes of democratization have taken place in many states where religion has a central influence and role in the public sphere. In some such countries, 'illiberal democracy' has developed. Indonesia is sometimes given as an example in this regard (Jamal, 2009: 4).

The opinion of Lipset (1959) in analyzing the implementation of Indonesian democracy is "a positive relationship between the level of economic development and a country's chances for a stable democracy, dozens of quantitative studies have examined this relationship". In Human Development Report 2002: Deepening Democracy in a Fragmented World (2002), it is stated that: "Promoting democratic means expanding capabilities such as education, to enable people to play a more effective role in such politics, and fostering the development of civil society groups and other informal institutions to help democratic institutions better represent the people"(UNDP, 2002: 5).

The concept developed by UNDP to develop human development and democracy is known as the Empowerment Theory. The theory seems to be more relevant to the situation in Indonesia, so through the development of democracy, systematic and programmed efforts will be made to encourage human progress, reduce poverty in the world, increase economic growth, encourage increased investment and increase opportunities for people to be more productive and creative as an asset of the nation.

In the course of democratization in Indonesia, it is inseparable from the inhibiting factors of democracy, namely:

1. The level of education in Indonesia is still lacking in understanding the meaning of discipline in society and deliberation. This has an impact on the lack of a broad view of someone who only pays more attention to themselves and the interests of their group. Resulting in a character that does not respect and accept the opinions of others. while the lack of discipline resulted in the law being less effective in society.

2. Low level of awareness of laws and regulations in force in Indonesia. Legal awareness in society towards Pancasila, the 1945 Constitution, and legislation is not evenly distributed and comprehensive, resulting in frequent abuse of authority. This is a challenge in itself for a democratic country like Indonesia which puts Pancasila as the life philosophy of its citizens.

3. The level of community welfare is still relatively low. In a battle arena for power like Indonesia, it is undeniable that each other and competes to 
exert all available strength to get what you want. The elite tends to take advantage of this situation and it is also enjoyed by the lower classes. So there was the practice of money politics and corruption in democratization in Indonesia. The level of public participation in politics that is still driven by money has made the arena of democracy in Indonesia a political jungle.

4. Feudalistic and Paternalistic Influences. The strength of feudalism in the past made people reluctant to express their opinions or opinions that were different from those of a higher position. Conversely, someone ignores the opinions of others who have a lower position than himself. The paternalistic culture is still closely related to the patron-client relationship pattern. Charismatic-paternalistic leadership, both structural and cultural, still occupies the top charts in leadership patterns in Indonesia.

5. Pessimistic and skeptical attitude towards democracy. Democracy is seen as part of the grand scenario that Western countries are offering to the world community. So there is an opinion that says that western society that gave birth to democracy has a culture that is different from Indonesian culture, and culture indeed has an influence on the implementation of democracy. However, every culture can be developed democracy. So democracy will not be the same in different cultural settings. Just as democracy in Japan will not be the same as democracy in America because of the different cultures between the two countries. However, all the differences caused by cultural differences do not eliminate the basic essence of democracy, namely sovereignty in the hands of the people.

6. The issue of SARA as a tool to weaken the existence of democracy. In Indonesian society, there is still frequent turmoil with the nuances of SARA (ethnicity, religion, race, and belief) which can disturb social life and cause political tension. From the differences in views between ethnic groups, races, religions, and groups in Indonesia, it can cause social unrest, especially because of the lack of understanding of the people who are often provoked about the issue of SARA. Therefore the issue of SARA can injure the essence of democracy.

According to Masykuri Abdillah $(2011 ; 45)$ that the success factors of the democratic transition in Indonesia are different from Arab countries, namely; a). A strong commitment from almost all components of the nation to practice democracy; b). A strong commitment from the military group to support the democratic transition; c). The political will of the presidents in the reform era to share power wherever possible (power-sharing) with existing political and social groups; d). The existence of strong civil society 
organizations such as Nahdlatul Ulama (NU) and Muhammadiyah, as Islamic organizations that support democracy and have a strong national vision, so that they can harmonize religious teachings with democracy, including ending the debate on the formalization of sharia Islam in the amendments to article 29 of the 1945 Constitution.

In line with the development of the democratization process in Indonesia, a term called "religious democracy" has emerged, which is a concept which on the one hand maintains the substance of democracy, and on the other hand, respects religious values and local culture in Indonesia. As for "religious", it includes all religions that have received formal recognition in Indonesia, namely Islam, Protestant Christianity, Catholicism, Hinduism, and Buddhism. According to Masykuri Abdillah, the concept of religious democracy has the following criteria: (1). The will of the people should not or as far as possible conflict with the precepts of the Supreme Lordship, (2). Public decisions should be accounted for both before humans and God (3). The orientation of each individual should emphasize not only rights but also obligations (4). Maintaining a balance between individual and collective rights and between material and spiritual values (Masykuri Abdillah, 2011: 51).

According to Michael Buehrerr (2009: 53), one of the reasons for the establishment of a harmonious relationship between Islam and democracy in Indonesia is the fragmentation of Islamic authority in shaping civil society or civil society. As explained also by Jhon $\mathrm{T}$ Sidel that the fragmentation of Islamic authority has not yet had a strong influence, instead it is exacerbated by the low institutionalization of political parties in Indonesia. Therefore, the involvement of Indonesian civil society in the democratization process has an impact on the success of Indonesian democracy both now and in the future. According to Azyumardi Azra (2017: 1) that Indonesian democracy is compatible with Islam so that Indonesia proves as a prime example where followers of Islam, Catholics, Protestants, Hindus, Buddhists, and Confucians can coexist peacefully and strengthen and respect each other so that religious harmony can be established with good in Indonesia. This can be done with a moderate understanding that seeks peace and harmony.

However, apart from those mentioned above, the existence of radicalism is also an inhibiting factor for democracy in Indonesia. Radicalism can lead to acts of terrorism in Indonesia. Democracy and religious revival are two major phenomena that emerged at the end of the 20th century, which is interesting between the two of them being related to one another. On the one hand, the absence of democracy in Muslim countries can foster religious revival 
movements, which in turn can lead to religious radicalism, one of which can be in the form of terrorism. On the other hand, the existence of democracy that provides freedom of speech thought, and expression can also give birth to religious revival movements that lead to radicalism and terrorism. Radicalism is synonymous with violence, this is due to symptoms in social reality that are often visible. radical groups often use violent means to fulfill their desires or interests. What is meant by religious radicalism is "a religious attitude which is rigid and at the same time contains violence in action" (Hanum, 2017).

According to Azyumardi Azra (2015: 1), the word "radical" is an adjective that means "prominently calling for or abandoning the ordinary way to then follow revolutionary and extreme ideologies and ways for comprehensive changes that have a broad and long impact". Meanwhile, radicalism is an ideology that believes that complete change can only be carried out by radical means, not by peaceful and evolutionary means. Furthermore, according to Azyumardi Azra (2016: 155), the term radical refers to groups, organizations, and even countries that are often accused by the West of being terrorists or of committing terrorism. Terrorism is one of the instruments of the perpetrators, while radicalism is the essence of the instrument itself. The term radical is also understood as the ideas and actions of groups that move to subvert established political orders, states or regimes that aim to weaken the political authority and legitimacy of other states and regimes, and countries that seek to adjust or change the existing power relations in the international system. Radicalism is intrinsically concerned with the concept of political and social change at various levels.

Radicalism arises due to various factors, one of which is precise because the principles of democratic governance and politics are not implemented. Then, the double standards that are practiced by Western countries, especially the United States, on political problems in the Islamic world, especially regarding the Arab-Israeli conflict. Fundamentalism and radicalism as long as they are only at the level of thought, are not a threat to democracy. It only threatens democracy when radicalism has led to acts of violence that have caused victims among civilians. However, similar violence is carried out by state institutions in the name of democracy. What non-state actors do to various public interests is an act of violence that can be classified as terrorism. However, acts of violence in certain countries, especially the United States and Israel, which cause casualties among civilians, such as in Palestine, Afghanistan, and Iraq are acts of terrorism. Therefore, looking at the problem of terrorism must be fair and not use double standards (Sihbudi: 2004). 
Currently, the political condition in Indonesia is relatively stable after going through a long process, in the transition stage of democracy, successfully carrying out political reforms. However, at the consolidation stage, democracy still finds obstacles and obstacles such as corruption, money politics, regional election conflicts, inter-ethnic conflicts, violence, and religious radicalism. The existence of control over state administration, democratic elections, freedom of opinion, expression, and freedom of the press indicates that Indonesia is a country that respects the principles of democracy as well as instills the values of Islamic teachings.

\section{b. Egypt}

When the Arab Spring expanded in the Middle East and even spread to Egypt, there was an assumption that what the countries experienced there was the beginning of the transition to a country whose government was managed by democratic means. The developments in Egypt indicate that this assumption is too strong. In Robert Putnam's (1994) research on ways to make democracy work well in the book Making Democracy Work. In a democracy, there must be differences of opinion, but democracy can only survive if there is an institutionalization of means to achieve common goals. There needs to be a procedure/rules of the game and there is an arena for expressing differences of opinion, even for conflict, but also for finding solutions. For Putnam, an institution is a tool to achieve purposes and not just a place to reach an agreement or determine values or rules of the game which in the future will be considered obligatory to bind citizens. This means that the government as one of the pillars of guarding democracy is obliged to anticipate various demands that have not even been voiced by its citizens, not to be suppressed but to find solutions so that in the future there is no deadlock in decision making.

Putnam provides very valuable information about the importance of people who want to be democratic to collect social capital for democracy. The capital is an agreement to continue to trust each other as a nation despite differences of opinion, and this is tied up in the social activities of civil society groups. This capital cannot grow instantly, because it takes time for trust between these groups to emerge (Kuncahyono, 2013: xx).

According to Samuel Huntington (1993) in his book The Third Wave asserts that the wave of democratization in its history has never been unidirectional, aka conical in one direction. There is no single pattern at the global level regarding the transition path to democracy. Egypt is relatively 
lucky because after Mubarak there is a desire to enter into a form of government that is "not the same as the Mubarak model", meaning that the authoritarian regime model is completely closed in terms of information and has a concentration of power in a handful of people, while others must fear isolation is taboo in the new Egypt. The problem is what "democracy" means to the Egyptian people there is no clearly defined meaning, and there is no agreement between them on this matter. This is homework for the Egyptian people, especially civil society groups.

For decades, the military in Egypt has had a dual function to maintain political stability. Many writings show that a military group in Egypt has a big stake every time there is a new leader in the country, namely because 5-40 percent of the economy in Egypt is managed and owned by the military. The affairs of the import of raw materials for industry, construction, production, and even the real-estate business were held by military men. The military is also often "used" by civilian politicians to perpetuate power. This kind of model is done by Mubarak.

The Freedom and Justice Party (Hizb al-'Adalah wa al-Hurriyyah) in Egypt is a party formed by the moderate Brotherhood, which supports democracy. The fact is that the party won the 2012 General Election with $47 \%$ of the vote and succeeded in fighting for Muhammad Mursi as President of Egypt. Meanwhile, the An-Nour Party is a party of the Salafi group which initially rejected democracy, but since the 2011 revolution, they have participated in the democratic process (Election) and received $24.4 \%$ votes. However, on July 3 , 2013, Mursi had to resign due to a coup by the military-led by General Abdel Fatah Al-Sisi who was supported by the opposition group, the secular-liberal group, and the loyalist Husni Mubarak.

A coup is an act that is very contrary to democracy and means that Egypt is returning to an authoritarian system under military rule. Ironically, AlSisi's actions received a lot of support from governments in Arab countries. There are several important notes related to Morsi's actions that sparked political tensions, namely; a). The Mursi government is considered to lack power-sharing and accommodation towards the aspirations of existing political and social groups; b). Mursi also seemed reluctant to make political compromises in dispute resolution and preferred to issue decrees; c). As a result of Muris's attitude, the military and opposition groups felt that they had lost their political privileges.

Seeing the facts above, the problem is not caused by theological problems regarding the affinity and harmonization of Islam and democracy, 
but by factors of political competition and the still low commitment and democratic political culture. Here we need to return to the point that true democracy is a democracy that is lived, exercised, and maintained as a mandate by civil society groups, voters, and the mass media. When the military is still accustomed to being given the role of maintaining political stability, even though civil society groups are shouting bickering and even fighting, this is a golden opportunity for the military to ask legitimacy for its ability to lead Egypt. Instead of looking for a solution for democracy, the military felt that it was given the wind to rule.

Democracy is a political concept that must grow and find its formula from within the country. The bitter experience in Egypt is not necessarily a death for democracy. In essence, Egypt is just starting to experiment with democracy, so it needs a lot of internal references on how to accommodate various interests, but still effective in pushing controversial change agendas.

\section{CONCLUSIONS}

Talks about Islam and democracy will continue to be hotly discussed along with the wave of democratization in Muslim countries. Since 2011 the Arab Spring has been born, which has resulted in serious problems and obstacles, both in Egypt, Tunisia, and Libya. Even in Indonesia and Turkey as Muslim countries that are considered the most democratic, democratic practices are also inseparable from challenges and obstacles. In essence, the process of democratization in a Muslim country must adapt to the culture and political conditions of each of these countries. The challenges of the democratization process in Muslim countries, namely ideology, natural resources, a common vision and mission in building the country, strong commitment from all components of the nation, political will of the head of state regarding powersharing, and strengthening dialogue with the people. Meanwhile, the obstacles are prolonged political, economic, and social instability so that they are prone to conflict and violence, political sectarianism, culture and religion, authoritarianism, and internal and external conflicts. According to Azyumardi Azra, a political system that is more prospective for building political stability and social cohesion is a democracy, based on its principles, character, and practice, democracy becomes a more sustainable political system (visible) because democracy can better accommodate the aspirations of citizens that are increasingly diverse in both fields. religion, politics, social, culture, and economy. Therefore the Muslim community should foster and empower civil society or civil society in the life of a state in Muslim countries. 


\section{REFERENCES}

\section{Books}

A. Ubaidillah, et al (2000), Pendidikan Kewarganegaraan (Civic Education), Demokrasi, HAM dan Masyarakat Madani, Cet I; Jakarta: IAIN Press.

Abdillah, M. (1999), Demokrasi Di Persimpangan Makna; Respon Intelektual Muslim Indonesia terhadap Konsep Demokrasi (1966-1993), Yogyakarta, Tiara Wacana.

Awang, A.H. (2007). Islam dan Demokrasi, Malaysia: PTS Islamika.

Azra, A. (1996), Pergolakan Politik Islam: Dari Fundamentalisme, Modernisme hingga Post-Modernisme, Jakarta: Paramadina.

Azra, A. (2016), Transformasi Politik Islam: Radikalisme, Khilafatisme, dan Demokrasi Jakarta: Prenada Media Group dan Pusat Pengkajian Islam dan Masyarakat (PPIM) UIN Syarif Hidayatullah Jakarta.

Depdikbud (1999), Kamus Besar Bahasa Indonesia, Cet I, Jakarta: Balai Pustaka.

Diamond, Juan J. Liz, Seymour Martin Lipset (ed) (1995), Politics in Developing Countries Comparing Experiences with Democracy, Boulder: London, USA.

Esposito \& John O. Voll (1999), Demokrasi Di Negara-Negara Muslim, Cet I; Bandung: Mizan.

Huwaydi, F. (1996), Demokrasi, Oposisi dan Masyarakat Madani: Isu-isu Besar Politik Islam, Bandung: Mizan.

Kamil, S. (2002), Islam \& Demokrasi: Telaah Konseptual \& Historis, Ciputat: Gema Media Pratama.

Kuncahyono, T. (2013), Tahrir Square Jantung Revolusi Mesir, Jakarta: Kompas.

Maarif, A.S. (1985), Islam dan Masalah Kenegaraan, Jakarta: LP3ES.

Masykuri Abdillah (2011), Islam dan Dinamika Sosial Politik di Indonesia, Jakarta : PT Gramedia.

Mufid, M. (2004), Politik Dalam Perspektif Islam, Jakarta : UIN Press.

Sjadzali, M. (1990), Islam dan Tata Negara: Ajaran, Sejarah dan Pemikiran, Jakarta : UI Press.

Sulaiman, S.J. (1988), "Shura and Democracy", In Charles Khurzan, Liberal Islam, Oxford: Oxford University Press.

Thaha, I. (2005), Demokrasi Religius, Jakarta : Teraju. John L. 
Umar, M. (2004), Islam dan Demokrasi di Indonesia; Kemenangan Abangan dan Sekuler, Jakarta: Institute for Social Empowerment and Democracy (INSED) bersama Lembaga Pencegah Korupsi.

United Nations Development Programme (UNDP) (2002), Human Development Report 2002: Deepening Democracy in a Fragmented World, Overview.

\section{Websites}

Azra, A. Demokrasi Indonesia kompatibel dengan Islam, http://kalbar.antaranews.com/berita/327893/azyumardi-azra-demokrasiindonesia-kompatibel-dengan-islam.

http://www.academia.edu/10348523/Faktor Penghambat Demokrasi di Indon esia

http://www.kompasiana.com/fauziah hanum/demokrasi-dan-radikalismeagama-hubungan-yang-berwajah-paradoks.

Jibraan, A. 2008, Relasi agama dan negara, http://saifudiendjsh.blogspot.com.

Sihbudi, R. (2004), Islam, Radikalisme dan Demokrasi, lipi.go.id.

\section{Journal Article \& Newspaper}

Abdillah, M. (30 Agustus 2016), Model demokrasi di Negara Muslim, Artikel Surat Kabar Kompas.

Azra, A. (7 April 2015), “Waspadai Paham Radikal”, Kompas.

Bubalo, A; Fealy, G; Mason, W. (2008), Zealous Democrats; Islamism and Democracy in Egypt, Indonesia, and Turkey, Lowy Institue for International Policy, Australia.

Buehrerr, M. (2009), Islam and Democracy in Indonesia, Insight Turkey vol. 11/No.4/2009.

Esposito, J.L; \& Piscatori, J. (1991), "Democratization and Islam", In Middle East Journal, Vol. 45, No.3, Winter.

Huntington, SP. (1991), "Democracy's Third Wave", In Journal of Democracy, Vol.2 No.2, Spring.

Iftihah, NR. (2014), Islam dan Demokrasi, Jurnal Islamuna Volume 1 Nomor 1 Juni.

Jamal, A. (2009), Democratizing State-Religion Relations: A Comparative Study of Turkey, Egypt, and Israel, Democratization Vol. 16 No. 6 December, Taylor \& Francis. 